\title{
Penambahan Bahan Organik pada Media Pertumbuhan \\ Krisan (Dendrathema grandiflora Tzvelve) secara In Vitro
}

\section{Addition Organic Substance in Media for In Vitro Growth of Chryshantehum (Dendrathema grandiflora Tzvelve)}

\author{
Megayani Sri Rahayu*, Hasrat Enggal Prayogi \\ ${ }^{1}$ Departemen Agronomi dan Hortikultura, Fakultas Pertanian, Institut Pertanian Bogor \\ (Bogor Agricultural University), Jl. Meranti, Kampus IPB Darmaga, Bogor 16680, Indonesia \\ Telp.\&Faks.62-251-8629353 e-mail agronipb@indo.net.id \\ *Penulis untuk korespondensi : megasetiawan23@yahoo.com
}

Disetujui 24 Desember 2013/ Published Online 10 Januari 2014

\begin{abstract}
This research aims to study the effect of addition various organic materials on the growth of chrysanthemum by in vitro. It was conducted at the Laboratory of Tissue Culture, Department of Agronomy and Horticulture. The experimental design was using a completely randomized design (CRD) with two factor. The first factor was media's treatment of organic material consists of seven standards (MSO without the organic material, banana peels $50 \mathrm{~g} / \mathrm{l}+1 / 2 \mathrm{MS}(1 / 2$ concentration of macro, micro and vitamin), banana peels $100 \mathrm{~g} / \mathrm{l}+1 / 2 \mathrm{MS}$, banana peels $150 \mathrm{~g} / \mathrm{l}+1 / 2 \mathrm{MS}$, purple sweet potato $50 \mathrm{~g} / \mathrm{l}+1 / 2 \mathrm{MS}$, purple sweet potato $100 \mathrm{~g} / \mathrm{l}+1 / 2 \mathrm{MS}$ and purple sweet potato $150 \mathrm{~g} / \mathrm{l}+1 / 2 \mathrm{MS})$. The second factor was the treatment of chrysanthemum varieties with two variety (Puspita Nusantara and Puspita Pelangi). The results showed that the addition of organic material in tissue culture media chrysanthemums influenced on plant height, number of leaves, number of roots, number of branches roots and root length. Chrysanthemum varieties influenced on plant height and number of leaves. The interaction between organic media and chrysanthemum varieties occured in plant height at 4-10 weeks after cultured.
\end{abstract}

Keywords: banana peel, Puspita Nusantara, Puspita Pelangi, organic substance, purple sweet potato tubers

ABSTRAK

Penelitian ini bertujuan untuk mempelajari pengaruh dari penambahan berbagai bahan organik terhadap pertumbuhan tanaman krisan secara in vitro, dilaksanakan di Laboratorium Kultur Jaringan Tanaman, Departemen Agronomi dan Hortikultura. Hasil penelitian diolah menggunakan metode Rancangan Acak Lengkap (RAL) dengan dua faktor. Faktor pertama adalah perlakuan media bahan organik terdiri atas tujuh taraf (MSO tanpa penambahan bahan organik, kulit pisang $50 \mathrm{~g} / \mathrm{l}+1 / 2 \mathrm{MS}(1 / 2 \mathrm{konsentrasi}$ hara makro, mikro dan vitamin), kulit pisang $100 \mathrm{~g} / \mathrm{l}+1 / 2 \mathrm{MS}$, kulit pisang $150 \mathrm{~g} / \mathrm{l}+1 / 2 \mathrm{MS}$, ubi jalar ungu $50 \mathrm{~g} / \mathrm{l}+1 / 2 \mathrm{MS}$, ubi jalar ungu $100 \mathrm{~g} / \mathrm{l}+1 / 2 \mathrm{MS}$ dan ubi jalar ungu $150 \mathrm{~g} / \mathrm{l}+1 / 2 \mathrm{MS})$. Faktor kedua adalah perlakuan varietas krisan dengan dua jenis (Puspita Nusantara dan Puspita Pelangi). Hasil penelitian menunjukkan bahwa penambahan bahan organik dalam media kultur jaringan krisan memberikan pengaruh terhadap tinggi tanaman, jumlah daun, jumlah akar, dan panjang akar. Varietas krisan memberikan pengaruh pada tinggi tanaman dan jumlah daun tanaman krisan. Interaksi antara media bahan organik dan varietas krisan terjadi pada tinggi tanaman umur 4-10 MSK.

Kata kunci: bahan organik, Puspita Nusantara, Puspita Pelangi, kulit pisang, umbi ubi jalar ungu

\section{PENDAHULUAN}

Tanaman hias merupakan salah satu komoditas hortikultura yang banyak diminati masyarakat, karena memiliki warna dan bentuk yang beragam, selain itu tanaman hias bermanfaat untuk memperindah lingkungan. Menurut Mattjik (2010) tanaman hias juga bermanfaat sebagai pemuas kebutuhan rohani dan memperindah ruangan sehingga banyak masyarakat yang 
membudidayakannya. Tanaman hias meliputi tanaman hias daun dan tanaman hias bunga. Salah satu jenis tanaman hias bunga adalah tanaman krisan (Dendrathema grandiflora Tzvelve). Daya tarik yang dimiliki tanaman krisan antara lain warna, tipe dan bentuknya yang beragam. Krisan juga dimanfaatkan dalam bidang kesehatan yaitu dikonsumsi sebagai teh herbal atau teh obat.

Data Badan Pusat Statistik Indonesia (2010) menunjukkan bahwa produksi tanaman krisan di Indonesia mulai meningkat dari tahun ke tahun. Peningkatan produksi ini menunjukkan bahwa Indonesia memiliki potensi usaha untuk tanaman krisan. Usaha bunga krisan di Indonesia memiliki peluang ekspor yang cukup besar seiring dengan peningkatan permintaan bunga krisan, jumlah penduduk dan perubahan gaya hidup masyarakat. Ekspor krisan dilakukan ke beberapa negara diantaranya Jepang, Arab Saudi, Kuwait, Pakistan dan Uni Emirat Arab (Dirjen Horti, 2012).

Permasalahan yang sekarang dihadapi adalah Indonesia masih mengimpor bibit dari luar negeri seperti Belanda, Jerman, Amerika Serikat dan Jepang. Bibit krisan yang dibutuhkan dalam jumlah banyak, sehingga dengan mengimpor bibit biaya produksi semakin mahal Ketersediaan bunga krisan secara kontinu juga diperlukan untuk memenuhi permintaan konsumen.

Masalah impor bibit dan kontinuitas ketersediaan bunga dapat diatasi melalui perbanyakan dengan teknik kultur in vitro. Kultur in vitro tanaman mempunyai potensi sangat besar dalam program pemuliaan tanaman serta penyediaan benih dan bibit berkualitas (Yuwono, 2008).

Media merupakan faktor penting dalam teknik kultur in vitro karena nutrisi untuk pertumbuhan eksplan hanya diperoleh dari media. Penelitian ini menggunakan bahan organik sebagai suplemen dalam media kultur in vitro.

Bahan organik yang digunakan adalah kulit pisang dan umbi ubi jalar ungu. Bahan organik ini dipilih karena mengandung nutrisi yang dibutuhkan dalam kultur jaringan. Nutrisi yang terkandung dalam bahan organik tersebut antara lain karbohidrat dan vitamin. Selain mengandung nutrisi yang bermanfaat, kulit pisang dan umbi ubi jalar ungu mudah didapatkan dan harganya murah.

Penelitian ini bertujuan untuk mempelajari pengaruh beberapa jenis media bahan organik terhadap pertumbuhan dua varietas tanaman krisan secara in vitro. Hipotesis dalam penelitian ini adalah terdapat media bahan organik terbaik dalam pertumbuhan tanaman krisan, terdapat varietas krisan dengan pertumbuhan terbaik pada media bahan organik dan terdapat interaksi antara media bahan organik dengan varietas krisan dalam pertumbuhan tanaman krisan.

\section{BAHAN DAN METODE}

Penelitian ini dilaksanakan di Laboratorium Kultur Jaringan Tanaman, Departemen Agronomi dan Hortikultura, Fakultas Pertanian, Institut Pertanian Bogor. Penelitian dilaksanakan pada bulan Maret 2012 sampai dengan bulan September 2012.

Bahan tanaman yang digunakan dalam penelitian ini adalah eksplan buku tunggal (single node) krisan (Dendrathema grandiflora Tzvelve) varietas Puspita Nusantara dan Puspita Pelangi yang diperoleh dari Balai Penelitian Tanaman Hias Segunung. Bahan lain yang digunakan adalah media dasar Murashige-Skoog (MS), agar-agar, sukrosa, $\mathrm{KOH}, \mathrm{HCl}$, air steril dan bahan sterilan (alkohol, bakterisida dan fungisida). Bahan untuk pembuatan media kultur jaringan dari bahan organik adalah bubur kulit pisang dan umbi ubi jalar ungu. Peralatan yang digunakan dalam penelitian ini adalah botol kultur, timbangan analitik, cawan petri, bunsen, gelas ukur, labu ukur, alat tanam, autoklaf, laminar air flow cabinet (LAFC) dan alat penghalus bahan organik (blender).

Rancangan penelitian yang digunakan adalah rancangan acak lengkap (RAL) yang disusun secara faktorial dengan menggunakan dua faktor. Faktor pertama adalah penambahan bahan organik dengan tujuh taraf yaitu, MS0 tanpa penambahan bahan organik, kulit pisang $50 \mathrm{~g} / \mathrm{l}+$ $1 / 2$ MS, kulit pisang $100 \mathrm{~g} / \mathrm{l}+1 / 2 \mathrm{MS}$, kulit pisang $150 \mathrm{~g} / \mathrm{l}+1 / 2 \mathrm{MS}$, ubi jalar ungu $50 \mathrm{~g} / \mathrm{l}+1 / 2 \mathrm{MS}$, ubi jalar ungu $100 \mathrm{~g} / 1+1 / 2 \mathrm{MS}$ dan ubi jalar ungu 150 $\mathrm{g} / 1+1 / 2 \mathrm{MS}$. Faktor kedua adalah varietas krisan dengan dua taraf, yaitu Puspita Nusantara dan Puspita Pelangi. Terdapat empat belas kombinasi perlakuan dengan sepuluh ulangan untuk masingmasing kombinasi. Setiap ulangan terdiri dari satu eksplan sebagai satuan amatan terkecil. Satu eksplan ditanam dalam satu botol. Total satuan amatan dalam penelitian ini adalah 140 eksplan di dalam 140 botol.

\section{Pelaksanaan Penelitian}

Peralatan yang digunakan dalam pembuatan media dicuci dengan deterjen sampai bersih kemudian disterilkan ke dalam autoklaf 
pada suhu $121{ }^{\circ} \mathrm{C}$ dengan tekanan 17.5 Psi selama satu jam. Alat-alat yang perlu disterilkan adalah alat tanam, cawan petri, botol kultur, gelas ukur dan Erlenmeyer.

Media yang perlu dibuat adalah media perbanyakan dan media perlakuan. Media perbanyakan yang digunakan adalah MS0 (media dasar MS tanpa zat pengatur tumbuh. Media untuk perlakuan menggunakan dua bahan organik yaitu kulit pisang dan ubi jalar ungu. Kedua bahan organik ini disterilkan, kemudian ditimbang sesuai perlakuan dan direbus. Setelah direbus, bahan organik diblender lalu dicampur dengan media dasar $1 / 2$ MS, kemudian diukur $\mathrm{pH}$ hingga 5.8. Selanjutnya media ditambahkan agar-agar dan gula pasir lalu dimasak hingga mendidih dan dimasukkan ke dalam botol kultur. Botol-botol ini ditutup dengan plastik dan diikat dengan karet. Setelah itu botol-botol dimasukkan dan disterilkan kedalam autoklaf selama 30 menit kemudian disimpan di dalam ruang media/kultur.

Penanaman eksplan dilakukan di dalam Laminar Air Flow Cabinet yang telah disterilkan dengan menyemprot alkohol $70 \%$ pada dindingnya. Eksplan yang disubkultur merupakan potongan batang satu buku tunggal (node) yaitu eksplan batang dengan satu mata tunas aksilar berukuran sekitar $3 \mathrm{~cm}$. Dalam penelitian ini eksplan yang ditanam pada media poerlakuan tidak mengikutsertakan pucuk meristem. Eksplan ditanam secara vertikal dengan posisi tidak boleh terbalik. Penanaman eksplan dalam media perlakuan sebanyak satu eksplan setiap botol. Pengamatan pertumbuhan eksplan dilakukan setiap minggu. Peubah yang diamati antara lain waktu pembentukan tunas dan kalus, tinggi tanaman, jumlah daun, jumlah akar dan persentase kontaminasi. Pengamatan penelitian ini dilakukan mulai dari minggu pertama hingga minggu ke sepuluh setelah dikulturkan (MSK).

\section{HASIL DAN PEMBAHASAN}

\section{Tinggi tanaman}

Salah satu peubah yang diamati untuk pertumbuhan tanaman krisan adalah tinggi tanaman. Tinggi tanaman diukur mulai titik tumbuh tunas hingga ujung pucuk tanaman. Pengukuran dilakukan setiap satu minggu sekali.

Pengamatan tinggi tanaman dilakukan dari 1 MSK sampai 10 MSK. Tanaman krisan yang berumur 1 MSK belum mengalami penambahan tinggi disebabkan baru muncul tunas. Penambahan tinggi tanaman di mulai pada 2 MSK. Tabel 1 menunjukkan bahwa media terlihat berpengaruh sangat nyata pada 8 MSK sampai 10 MSK. Varietas krisan memberikan pengaruh sangat nyata terhadap tinggi tanaman pada 8 MSK sampai 10 MSK. Interaksi kedua faktor memberikan perngaruh sangat nyata pada 8-9 MSK dan berpengaruh nyata pada 10 MSK.

Tabel 1. Rekapitulasi analisis ragam pengaruh media dan varietas terhadap tinggi tanaman krisan

\begin{tabular}{ccccc}
\hline $\begin{array}{c}\text { Umur } \\
(\mathrm{MSK})\end{array}$ & Media & Varietas & $\begin{array}{c}\text { Interaksi media dan } \\
\text { varietas }\end{array}$ & KK $(\%)$ \\
\hline 8 & $* *$ & $* *$ & $* *$ & 16.87 \\
9 & $* *$ & $* *$ & $* *$ & 17.64 \\
10 & $* *$ & $* *$ & $*$ & 18.55 \\
\hline
\end{tabular}

Keterangan : $\left.{ }^{* *}\right)$ berpengaruh sangat nyata $\left.\mathrm{p} \leq 0.01 ; *\right)$ berpengaruh nyata $\mathrm{p} \leq 0.05 ; \mathrm{tn}=$ tidak nyata; $\mathrm{KK}=\mathrm{Koefisien}$ keragaman; data di transformasi $(x+2)^{1 / 2}$ sebelum diolah menggunakan SAS

Media bahan organik memberikan pengaruh sangat nyata terhadap pertumbuhan tinggi tanaman krisan diduga karena adanya kandungan karbohidrat yang terdapat dalam media tersebut. Menurut Widiastoety dan Bahar (1995) karbohidrat merupakan sumber karbon dan energi. Sumber karbon dan energi yang sering digunakan adalah sukrosa dan glukosa. Senyawasenyawa organik tersebut selain sebagai bahan baku yang menghasilkan energi dalam proses respirasi juga sebagai bahan pembentuk sel-sel baru.
Rata-rata tinggi tanaman krisan tertinggi pada akhir penagamtan (10 MSK) terdapat pada krisan varietas Puspita Pelangi dengan perlakuan media ubi jalar ungu $100 \mathrm{~g} / \mathrm{l}$ yaitu $11.13 \mathrm{~cm}$ sedangkan rata-rata tinggi tanaman krisan terendah terdapat pada krisan varietas Puspita Nusantara dengan perlakuan media kulit pisang $150 \mathrm{~g} / \mathrm{l}$. Media perlakuan dengan penambahan ubi jalar ungu $100 \mathrm{~g} / \mathrm{l}+\mathrm{MS} \quad 1 / 2$ sesuai untuk pertumbuhan tinggi tanaman krisan karena ubi jalar ungu mengandung karbohidrat yang cukup tinggi. Hasil ini berbeda dengan penelitian Widyastoety dan Purbadi (2003) dimana pada 
penelitian tersebut ubijalar ungu dianggap menghambat pertmbuhan tinggi planlet anggrek. Menurut Gunawan (1992) penggunaan bahan organik sebagai bahan tambahan media dapat berbeda pengaruhnya pada tanaman yang berbeda pula.

Tabel 2. Interaksi media dan varietas krisan terhadap tinggi tanaman krisan

\begin{tabular}{|c|c|c|c|c|c|c|c|}
\hline \multirow{3}{*}{ Varietas } & \multicolumn{7}{|c|}{ Media Perlakuan } \\
\hline & \multicolumn{7}{|c|}{ Tinggi tanaman $(\mathrm{cm}) / 8 \mathrm{MSK}$} \\
\hline & $\mathrm{O} 0$ & $\mathrm{O} 1$ & $\mathrm{O} 2$ & $\mathrm{O} 3$ & $\mathrm{O} 4$ & O5 & O6 \\
\hline V1 & $1.75 \mathrm{f}$ & $4.28 \mathrm{~d}$ & $2.36 \mathrm{ef}$ & $1.10 \mathrm{f}$ & 3.80de & $5.92 \mathrm{~cd}$ & $5.03 \mathrm{~cd}$ \\
\hline $\mathrm{V} 2$ & $9.30 \mathrm{ab}$ & $8.68 \mathrm{ab}$ & $5.75 \mathrm{~cd}$ & $2.27 \mathrm{ef}$ & $9.04 \mathrm{ab}$ & $9.70 \mathrm{a}$ & $6.69 \mathrm{bc}$ \\
\hline \multicolumn{8}{|c|}{ Tinggi Tanaman $(\mathrm{cm}) / 9$ MSK } \\
\hline & $\mathrm{O} 0$ & $\mathrm{O} 1$ & $\mathrm{O} 2$ & $\mathrm{O} 3$ & $\mathrm{O} 4$ & O5 & O6 \\
\hline V1 & $2.23 \mathrm{~d}$ & $4.85 \mathrm{bc}$ & $3.09 \mathrm{~cd}$ & $1.42 \mathrm{~d}$ & $4.64 b c$ & $6.57 \mathrm{~b}$ & $5.49 \mathrm{~b}$ \\
\hline $\mathrm{V} 2$ & $9.98 \mathrm{a}$ & $9.61 \mathrm{a}$ & $6.60 \mathrm{~b}$ & $2.63 \mathrm{~d}$ & $9.74 \mathrm{a}$ & $10.46 \mathrm{a}$ & $7.38 \mathrm{ab}$ \\
\hline \multicolumn{8}{|c|}{ Tinggi Tanaman $(\mathrm{cm}) / 10$ MSK } \\
\hline & $\mathrm{O} 0$ & $\mathrm{O} 1$ & $\mathrm{O} 2$ & $\mathrm{O} 3$ & $\mathrm{O} 4$ & O5 & O6 \\
\hline V1 & $2.77 \mathrm{e}$ & $5.54 \mathrm{~cd}$ & $3.53 \mathrm{de}$ & $1.90 \mathrm{e}$ & $5.57 \mathrm{~cd}$ & $7.02 \mathrm{bc}$ & $6.39 c$ \\
\hline $\mathrm{V} 2$ & $10.79 a$ & $10.26 \mathrm{ab}$ & $7.28 b c$ & $3.27 \mathrm{e}$ & $9.91 \mathrm{ab}$ & $11.13 \mathrm{a}$ & 7.98abc \\
\hline
\end{tabular}

Keterangan : Rataan yang diikuti huruf sama tidak berbeda nyata pada DMRT 5\%, V1 : Puspita Nusantara, V2 : Puspita Pelangi, O0: MS0, O1: Kulit pisang $50 \mathrm{~g} / 1+1 / 2 \mathrm{MS}$, O2: Kulit pisang $100 \mathrm{~g} / 1+1 / 2 \mathrm{MS}$, O3: Kulit pisang $150 \mathrm{~g} / 1+1 / 2 \mathrm{MS}$, O4: Ubi jalar ungu $50 \mathrm{~g} / 1+1 / 2 \mathrm{MS}$, O5: Ubi jalar ungu $100 \mathrm{~g} / 1+1 / 2 \mathrm{MS}$, O6: Ubi jalar ungu $150 \mathrm{~g} / \mathrm{l}+1 / 2 \mathrm{MS}$, data ditransformasi $(\mathrm{x}+2)^{1 / 2}$ sebelum diolah menggunakan SAS

\section{Jumlah daun}

Jumlah daun tanaman krisan mulai diamati dari 1-10 MSK. Daun yang diamati adalah daun yang telah membuka sempurna. Penghitungan jumlah daun dimulai dari daun baru yang muncul. Daun tanaman krisan belum tumbuh pada minggu pertama pengamatan, dan mulai tumbuh pada minggu kedua pengamatan.

Tabel 3 menunjukkan bahwa perlakuan media memberikan pengaruh sangat nyata dan varietas memberikan pengaruh nyata terhadap jumlah daun tanaman krisan. Interaksi dua faktor tidak memberikan pengaruh nyata terhadap jumlah daun tanaman krisan.

Daun pada tanaman krisan yang berumur 8- 10 MSK ada yang layu/berwarna coklat sehingga tidak dimasukkan dalam pengamatan. Daun tersebut kemudian mati. Hal ini disebabkan tanaman krisan seharusnya disubkultur pada media yang baru.

Tabel 3. Rekapitulasi analisis ragam pengaruh media dan varietas terhadap jumlah daun tanaman krisan

\begin{tabular}{ccccc}
\hline $\begin{array}{c}\text { Umur } \\
(\mathrm{MSK})\end{array}$ & Media & Varietas & $\begin{array}{c}\text { Interaksi media dan } \\
\text { varietas }\end{array}$ & $\mathrm{KK}(\%)$ \\
\hline 8 & $* *$ & $*$ & tn & 16.29 \\
9 & $* *$ & $*$ & tn & 16.79 \\
10 & $* *$ & $*$ & tn & 17.56 \\
\hline
\end{tabular}

Keterangan : $\left.{ }^{* *}\right)$ berpengaruh sangat nyata $\left.\mathrm{p} \leq 0.01 ; *\right)$ berpengaruh nyata $\mathrm{p} \leq 0.05 ; \mathrm{tn}=$ tidak nyata; $\mathrm{KK}=$ Koefisien keragaman; data ditransformasi $(\mathrm{x}+2)^{1 / 2}$ sebelum diolah menggunakan SAS

Tabel 4 menunjukkan rata-rata jumlah daun terbanyak terdapat pada perlakuan media ubi jalar ungu $100 \mathrm{~g} / \mathrm{l}$ yaitu 11.75 daun, tetapi perlakuan media tersebut tidak berbeda nyata hasilnya dengan perlakuan media bahan organik kulit pisang $50 \mathrm{~g} / \mathrm{l}$, kulit pisang $100 \mathrm{~g} / \mathrm{l}$, ubi jalar ungu $50 \mathrm{~g} / \mathrm{l}$ dan ubi jalar ungu $150 \mathrm{~g} / \mathrm{l}$. Perlakuan media memberikan pengaruh terhadap rataan jumlah daun diduga karena kandungan protein pada media bahan organik. Dua bahan organik tersebut mengandung protein (lampiran 3 dan 4). Protein disusun salah satunya oleh nitrogen. 
Nitrogen berfungsi untuk pertumbuhan vegetatif tanaman. Menurut Saifudin dalam Matatula (2003) apabila nitrogen yang tersedia lebih banyak dari unsur lainnya, maka tanaman akan menghasilkan protein lebih banyak dan daun dapat tumbuh lebih lebat.

Tabel 4. Pengaruh media terhadap jumlah daun tanaman krisan

\begin{tabular}{cccccccc}
\hline \multirow{2}{*}{$\begin{array}{c}\text { Umur } \\
\text { (MSK) }\end{array}$} & \multicolumn{7}{c}{ Jumlah daun (helai) } \\
\cline { 2 - 7 } & O0 & O1 & O2 & O3 & O4 & O5 & O6 \\
\hline & $6.70 \mathrm{bc}$ & $8.85 \mathrm{a}$ & $7.34 \mathrm{ab}$ & $4.97 \mathrm{c}$ & $8.20 \mathrm{ab}$ & $9.05 \mathrm{a}$ & $8.40 \mathrm{ab}$ \\
9 & $7.65 \mathrm{bc}$ & $9.55 \mathrm{a}$ & $8.07 \mathrm{ab}$ & $5.52 \mathrm{c}$ & $8.75 \mathrm{ab}$ & $10.30 \mathrm{a}$ & $9.19 \mathrm{ab}$ \\
10 & $8.50 \mathrm{bc}$ & $10.80 \mathrm{a}$ & $9.39 \mathrm{ab}$ & $6.12 \mathrm{c}$ & $9.80 \mathrm{ab}$ & $11.75 \mathrm{a}$ & $10.08 \mathrm{ab}$ \\
\hline
\end{tabular}

Keterangan : Rataan yang diikuti huruf yang sama pada baris yang sama tidak berbeda nyata pada DMRT $5 \%$,

O0:MS0, O1: Kulit pisang $50 \mathrm{~g} / 1+1 / 2 \mathrm{MS}$, O2: Kulit pisang $100 \mathrm{~g} / 1+1 / 2 \mathrm{MS}$, O3: Kulit pisang $150 \mathrm{~g} / 1+1 / 2$ MS, O4: Ubi jalar ungu $50 \mathrm{~g} / \mathrm{l}+1 / 2 \mathrm{MS}$, O5: Ubi jalar ungu $100 \mathrm{~g} / \mathrm{l}+1 / 2 \mathrm{MS}$, O6: Ubi jalar ungu $150 \mathrm{~g} / 1+1 / 2 \mathrm{MS}$, data ditransformasi $(\mathrm{x}+2)^{1 / 2}$ sebelum diolah menggunakan SAS

Rata-rata jumlah daun terendah diperoleh pada perlakuan media bahan organik kulit pisang $150 \mathrm{~g} / \mathrm{l}$ yaitu 6.12 daun. Menurut Widiastoety dan Nurmalinda (2010) dalam jaringan daun yang mengalami tekanan osmotik terdapat akumulasi asam absisat (ABA) di dalam jaringan tanaman yang dapat menghambat pertumbuhan tanaman. Selain akumulasi ABA, terjadi pula penghambatan sintetis sitokinin yang meningkatkan hambatan pertumbuhan yang diakibatkan oleh pengaruh ABA. Tabel 5 menunjukkan bahwa varietas krisan Puspita Pelangi memiliki jumlah daun yang lebih banyak dibandingkan krisan varietas Puspita Nusantara, tetapi secara statistik menunjukkan hasil yang tidak berbeda nyata.

Tabel 5. Pengaruh varietas krisan terhadap jumlah daun tanaman krisan

\begin{tabular}{cccc}
\hline \multirow{2}{*}{ Varietas } & \multicolumn{3}{c}{ Jumlah daun (helai) } \\
\cline { 2 - 4 } & 8 & 9 & 10 \\
\hline V1 & $7.27 \mathrm{a}$ & Umur (MSK) & $9.00 \mathrm{~b}$ \\
V2 & $8.01 \mathrm{a}$ & $8.02 \mathrm{a}$ & $9.99 \mathrm{a}$ \\
\hline
\end{tabular}

Keterangan : Rataan yang diikuti huruf yang sama pada kolom yang sama tidak berbeda nyata pada DMRT 5\%, V1 : Varietas Puspita Nusantara, V2 : Varietas Puspita Pelangi, data ditransformasi $(\mathrm{x}+2)^{1 / 2}$ sebelum diolah menggunakan SAS

\section{Jumlah akar}

Pengamatan jumlah akar dilakukan mulai 1 MSK sampai 10 MSK. Rekapitulasi analisis sidik ragam pada Tabel 6 menunjukkan bahwa perlakuan media bahan organik memberikan pengaruh yang sangat nyata terhadap jumlah akar pada 8 MSK dan berpengaruh nyata pada 9- 10 MSK dan perlakuan varietas krisan tidak memberikan pengaruh nyata dari awal hingga akhir pengamatan. Pengamatan pada minggu pertama menunjukkan eksplan krisan belum berakar..Akar tanaman krisan terbentuk setelah berumur 2 MSK. Akar yang terbentuk berukuran kecil dan tipis. Akar ini yang menyerap unsur hara dalam media kultur jaringan. Akar pada tanaman krisan ukurannnya cukup panjang sehingga akan melingkar di dalam dasar botol kultur. 
Tabel 6. Rekapitulasi analisis ragam pengaruh media dan varietas terhadap jumlah akar tanaman krisan

\begin{tabular}{ccccc}
\hline Umur $($ MSK) & Media & Varietas & Interaksi media dan varietas & KK $(\%)$ \\
\hline 8 & $* *$ & tn & tn & 16.62 \\
9 & $*$ & tn & tn & 16.81 \\
10 & $*$ & tn & tn & 17.00 \\
\hline
\end{tabular}

Keterangan : $\left.{ }^{* *}\right)$ berpengaruh sangat nyata $\left.\mathrm{p} \leq 0.01 ;{ }^{*}\right)$ berpengaruh nyata $\mathrm{p} \leq 0.05 ; \mathrm{tn}=$ tidak nyata; $\mathrm{KK}=$ Koefisien keragaman; data ditransformasi $(\mathrm{x}+2)^{1 / 2}$ sebelum diolah menggunakan SAS

Tabel 7. Pengaruh media terhadap jumlah akar tanaman krisan

\begin{tabular}{|c|c|c|c|c|c|c|c|}
\hline \multirow{3}{*}{$\begin{array}{c}\text { Umur } \\
\text { (MSK) }\end{array}$} & \multicolumn{7}{|c|}{ Jumlah akar } \\
\hline & \multicolumn{7}{|c|}{ Media } \\
\hline & $\mathrm{O} 0$ & O1 & $\mathrm{O} 2$ & $\mathrm{O} 3$ & $\mathrm{O} 4$ & O5 & O6 \\
\hline 8 & $4.25 \mathrm{a}$ & $4.30 \mathrm{a}$ & $3.54 \mathrm{ab}$ & $2.60 \mathrm{~b}$ & $4.00 \mathrm{a}$ & $4.75 \mathrm{a}$ & $4.76 a$ \\
\hline 9 & $4.35 \mathrm{a}$ & $4.35 \mathrm{a}$ & 3.69ab & $2.70 \mathrm{~b}$ & $4.10 \mathrm{a}$ & $4.90 \mathrm{a}$ & $4.76 a$ \\
\hline 10 & $4.45 \mathrm{a}$ & $4.45 \mathrm{a}$ & $4.24 \mathrm{ab}$ & $3.12 \mathrm{~b}$ & $4.15 \mathrm{ab}$ & $5.00 \mathrm{a}$ & $5.09 a$ \\
\hline
\end{tabular}

Keterangan : Rataan yang diikuti huruf yang sama pada baris yang sama tidak berbeda nyata pada DMRT 5\%, O0: MS0, O1: Kulit pisang $50 \mathrm{~g} / 1+1 / 2$ MS, O2: Kulit pisang $100 \mathrm{~g} / \mathrm{l}+1 / 2 \mathrm{MS}$, O3: Kulit pisang $150 \mathrm{~g} / \mathrm{l}+$ $1 / 2$ MS, O4: Ubi jalar ungu $50 \mathrm{~g} / \mathrm{l}+1 / 2 \mathrm{MS}$, O5: Ubi jalar ungu $100 \mathrm{~g} / \mathrm{l}+1 / 2 \mathrm{MS}$, O6: Ubi jalar ungu 150 $\mathrm{g} / \mathrm{l}+1 / 2 \mathrm{MS}$, data ditransformasi $(\mathrm{x}+2)^{1 / 2}$ sebelum diolah menggunakan SAS

Tabel 7 menunjukkan rata-rata jumlah akar tanaman krisan terbanyak pada penelitian ini adalah 5.09 akar diperoleh dari tanaman krisan yang ditanam pada media ubi jalar ungu $150 \mathrm{~g} / \mathrm{l}$. Perlakuan media ubi jalar ungu $150 \mathrm{~g} / \mathrm{l}$ tidak berbeda nyata dengan perlakuan media MS0, kulit pisang $50 \mathrm{~g} / \mathrm{l}$, kulit pisang $100 \mathrm{~g} / \mathrm{l}$, ubi jalar ungu $50 \mathrm{~g} / \mathrm{l}$, dan ubi jalar ungu $100 \mathrm{~g} / \mathrm{l}$. Rata-rata jumlah akar paling sedikit terdapat pada tanaman krisan yang ditanam pada media kulit pisang 150 $\mathrm{g} / \mathrm{l}$.

Media bahan organik memberikan pengaruh terhadap rataan jumlah akar diduga karena Salah satu kandungan gizi dari kulit pisang dan ubi jalar ungu adalah fosfor (P). Hara ini berfungsi untuk pertumbuhan akar, oleh karena itu dalam perlakuan media bahan organik terdapat respon yang cukup baik dalam pembentukan akar tanaman krisan (Trigiano dan Gray, 2005).

\section{KESIMPULAN}

Perlakuan media memberikan pengaruh pada semua peubah yang diamati yaitu tinggi tanaman, jumlah daun, jumlah akar, jumlah cabang akar dan panjang akar terpanjang. Tanaman krisan yang ditanam pada media ubi jalar ungu $100 \mathrm{~g} / \mathrm{l}$ cenderung memberikan pertumbuhan terbaik dibandingkan dengan perlakuan media lainnya. Perlakuan varietas tidak berbeda nyata pada peubah jumlah akar, panjang akar terpanjang dan berpengaruh nyata pada peubah tinggi tanaman dan jumlah daun. Media dan varietas krisan memiliki interaksi pada peubah tinggi tanaman. Pada peubah jumlah daun, jumlah akar tidak terjadi interaksi antara media bahan organik dan varietas.

\section{DAFTAR PUSTAKA}

[BPS] Badan Pusat Statistika (ID). 2010. Luas Panen, Produksi dan Produktivitas Tanaman Krisan, 2009-2010. http://www.bps.go.id/ [ 17 Oktober 2011 ]

[Dirjen Horti]. Direktorat Jendral Hortikultura. c2012. Ekspor per negara tujuan komoditas utama florikultura tahun 2009. http://hortikultura.deptan.go.id/index.php? option $=$ com_content $\&$ view $=$ article $\& i d=36$ 6\&Itemid=705 [diunduh 15 Februari 2012]

Mattjik NA. 2010. Budi Daya Bunga Potong \& Tanaman Hias. Agus P, editor. Bogor (ID): IPB Press.

Matatula AJ. 2003. Substitusi media MS dengan air kelapa dan gandasil-D pada kultur jaringan krisan. Eugenia 9(4):203-211.

Nugroho Kristianto. 2012. Pengaruh penambahan IAA dan Kinetin terhadap pertumbuhan krisan (Dendrathema grandiflora Tzvelve) 
varietas Pitaloka secara in vitro [Skripsi]. Bogor: Institut Pertanian Bogor.

Trigiano R N D J Gray. 2005. A brief introduction to plant anatomy.p.73-85. In : R.N. Trigiano and D.J.Gray (Eds.). Plant Development and Biotecnology. CRC.Press.Boca Raton.

Widiastoety D, Bahar FA. 1995. Pengaruh berbagai sumber dan kadar karbohidrat terhadap pertumbuhan planlet anggrek Dendrobium.J.Hor. 5(3):76-80

Widiastoety D, Nurmalinda. 2010. Pengaruh suplemen nonsintetik terhadap pertumbuhan planlet anggrek vanda. $J$. Hor. 20(1):60-66

Yuwono Triwibowo. 2008. Bioteknologi Pertanian. Yogyakarta (ID): Gadjah Mada Univ Press. 